\title{
Multivariate Statistical Analysis Applied to Water Quality of a Tropical Coastal Lagoon, Cartagena, Colombian Caribbean
}

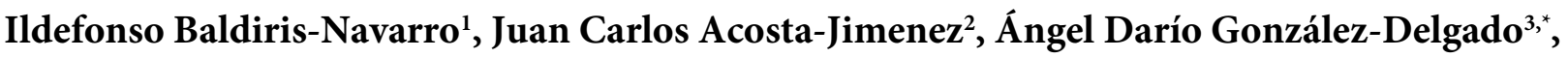 \\ Álvaro Realpe-Jiménez ${ }^{3}$, and Juan Gabriel Fajardo-Cuadro ${ }^{4}$ \\ ${ }^{1}$ SENA CINAFLUP-Cartagena, Cr. A Mamonal \#15, Cartagena de Indias, Colombia \\ ${ }^{2}$ Fundacion Universitaria Tecnológico Comfenalco, Cra. 44 \#30a-91, 130015, Cartagena de Indias, Colombia \\ ${ }^{3}$ University of Cartagena, Avenida del Consulado, Cll. 30 \# 48-152, 130015, Cartagena de Indias, Colombia \\ ${ }^{4}$ Universidad Tecnológica de Bolívar, Cra.21 \#25-92 Manga, 130001, Cartagena de Indias, Colombia
}

\section{* Corresponding author:}

tel: $+57-3164942938$

email: agonzalezd1@unicartagena.edu.co

Received: January 26, 2019

Accepted: July 1, 2019

DOI: $10.22146 /$ ijc.43035

\begin{abstract}
Coastal lagoons are one of the most threatened ecosystems in the world, because of population growth, habitat destruction, pollution, wastewater, overexploitation and invasive species which are the main causes of their degradation. The objective of this paper was to evaluate the water quality behavior in a stressed coastal lagoon in Cartagena, Colombian Caribbean. Environmental data was analyzed using hypothesis testing, confidence intervals, and also Principal components analysis (PCA). The study was focused on water parameters such as dissolved oxygen (DO), biochemical oxygen demand $\left(B O D_{5}\right)$, chemical oxygen demand (COD), salinity, $p H$, total dissolved solids, total coliforms (TC), Fecal coliforms (FC), ammonium $\left(\mathrm{NH}_{4}^{+}\right)$ and total phosphorus (TP). The analysis was conducted in line with the Colombian national water standard. Results showed that $B O D_{5}, C O D$, phosphorus, and coliforms are out of the limits permitted for these variables in Colombia and are reaching levels that may be a threat to human health. Principal components analysis detected five components that explained $79.4 \%$ of the variance of data and showed that anthropogenic and temporal factors might be affecting the variation of the parameters.
\end{abstract}

Keywords: coastal lagoon; water quality; statistics; multivariable analysis; Colombia

\section{- INTRODUCTION}

Worldwide, coastal areas are densely populated ecosystems of high ecological, economic, and social importance. Coastal lagoons, in particular, play an important role as productive ecosystems, species-rich habitats, and areas for storm protection and tourism. The main services provided by coastal systems include food provisioning (mainly fish and shellfish), freshwater storage, hydrological balance, climate regulation, flood protection, water purification, oxygen production, fertility, recreation, and ecotourism [1-2]. Nowadays, coastal lagoons are one of the most threatened ecosystems in the world, because of population growth, habitat destruction, pollution, wastewater, overexploitation and invasive species which are the main causes of their degradation [3].
Coastal lagoons are particular ecosystems where many interests may conflict, from fisheries to tourism, and from aquaculture to harbor facilities or urban development. In developing countries, water-related tourism is an increasing source of incomes. Clean water contributes to the recreation and tourism industry; that is why quality water availability is often considered the main limiting factor for developing tourism [4]. In the touristic city of Cartagena, which is visited by millions of tourists every year, there is an inner water body named Cabrero lagoon, which is highly impacted by subnormal population growth and other human activities. People living near the lagoon are extremely poor, and they found a place to live in the shores of it. This unauthorized urbanization of the lagoon has been 
bringing untreated wastewater that is discharged without any treatment directly into the lagoon. Solid wastes and fecal matter are also a problem for the ecosystem because people throw them into the water, leading to serious issues on lagoon health [5].

Descriptive statistics (mean, SD, among others) and some graphical tools may give a simple assessment of water behavior. Inferential statistics have tools like hypothesis testing and confidence intervals that may help to assess the performance of a water body in a period [6]. The problem of evaluating water quality becomes more and more complicated as we increase the number of measured variables; then the use of both multivariate techniques and data reduction are almost mandatory to achieve satisfactory results. Multivariate analysis techniques such as principal components analysis (PCA) may be used to analyze large databases without losing valuable information [7] and allow monitoring of all the variables and their relations simultaneously. PCA technics have been widely used to evaluate water quality, identify the latent sources that influence surface water, and offer a valuable tool for reliable management of water resources as well as effective solutions to pollution in the last decade $[6,8]$.

Mitra et al. assessed the water quality in Hooghly River Estuary, India, using PCA and cluster analysis [9]. Taoufik et al. studied the variation of water quality in the River Wadi El Bey for two years using PCA and cluster analysis [10]. Hajigholizadeh and Melesse [11] used cluster analysis and discriminant analysis to study southern Florida water quality, analyzing a 15-year database and over 35,000 observations to assess the state of water pollution and its time-space variation. Tosic et al. [12] used basic descriptive statistics to explain the temporal variation of water quality and sediments in the Bay of Cartagena. Yoon et al. [13] studied the temporal and spatial variation in Chilika lagoon using PCA and data collected from 1999 to 2009. Jung et al. [14] analyzed the behavior of water quality in the Nakdong River basin by principal component analysis and cluster analysis. Through principal component analysis and cluster analysis, Jiang et al. [15] studied the distribution of arsenic and other compounds in groundwater in Mongolia.
Marinovic and Ruzdjak [16] by PCA and CA analyses determined a baseline of water quality of the Sava River in Croatia after the war in this country.

The aim of this research was to analyze the temporal variability and the fulfillment of the Colombian environmental law of marine water quality in Cabrero lagoon using a data set of 9 years (2008-2017) which contains parameters such as: $\mathrm{pH}$, salinity, dissolved oxygen (DO), total suspended solids (TSS), total coliform (TC), fecal coliforms (FC), total phosphorus (TP), ammonium $\left(\mathrm{NH}_{4}^{+}\right)$, biochemical oxygen demand (BOD5) and chemical oxygen demand (COD), in order to provide better tools for the environmental management of this marine resource.

\section{- EXPERIMENTAL SECTION}

\section{Study Area}

Cabrero lagoon located at coordinates $10^{\circ} 25^{\prime} 52.8^{\prime \prime}$ $\mathrm{N} 75^{\circ} 32^{\prime} 27^{\prime \prime} \mathrm{W}$, has an approximate length of $1.38 \mathrm{~km}$, a water area of about 26 hectares and an average depth of $2.3 \mathrm{~m}$. This Cartagena's inner lagoon is connected to different highly polluted water bodies through channels, which are also connected to the Caribbean Sea. In this lagoon, the mangrove ecosystem is constituted by Rhizophora mangle L., Avicennia germinans L., Laguncularia racemose L., and Conocarpus erectus. The study area is characterized by exhibiting two climatic periods; one of rainfall between April and November, and the other period is dry and goes from December to April [17].

\section{Analytical Procedures}

In situ studied parameters were dissolved oxygen (SM 4500-O G), pH (SM 4500-H+) and salinity (SM2520-B), measures were done with the help of a portable water analysis kit (multi-parameter - Hach 5465011 SensIon). Parameters of biological oxygen demand was performed by Winkler method (SM 4500-O G), chemical oxygen demand (COD) by closed reflux, and total phosphorus by ascorbic method (SM 4500-P B, E). In addition, ammonium (SM 4500-NH3 B, C), total coliforms (SM 9222B), fecal coliforms and total suspended solids (SM 2540D) were analyzed in the 
laboratory following the standard methods for water and wastewater analysis. Data were then compared to the threshold values of the water quality law (decree 15941984) adopted by the government of Colombia [18-19].

\section{Data Analysis}

In order to evaluate the compliance of the Colombian environmental law in Cabrero lagoon, confidences intervals, and hypothesis testing were conducted toward the physicochemical and microbiological data gathered from 2000 to 2017. Nonparametric Wilcoxon signed-rank test was used to detect possible differences between the medians of water quality variables during dry and rainy periods. Principal components analysis was applied to obtain composite variables, which was expected to identify factors affecting water quality and latent pollution sources.

\section{Hypothesis testing and confidence interval}

A statistical hypothesis is a statement about the parameters of one or more populations; it involves measuring the strength of evidence provided by sample data. In particular, hypothesis testing involves formulating opposing statements- the null and alternative hypothesisabout the population parameter of interest. The goal of hypothesis testing is to decide whether or not to support the original claim, based on whether we reject the null hypothesis. To do so, a sample statistic is measured or observed, and a decision is made to reject or fail to reject the null Hypothesis based on the extremity of the sample statistic. This decision is based on the probability, called the $p$-value, of observing the sample statistic, under the assumption that the null hypothesis is true. If the $p$-value is smaller than 0.05 , then we reject the null hypothesis. Hypothesis testing is an effective tool to compare the mean of a population to a specified value. In this research hypothesis testing will be used to evaluate the accomplishment of the Colombian water law (see Table 1).

A confidence interval gives an estimated range of values which is likely to include an unknown population parameter. The estimated range is calculated from a given set of sample data. The interval has an associated confidence level that quantifies the level of confidence that the parameter lies in the interval [20-21].

\section{Wilcoxon signed-rank test}

Wilcoxon signed-rank test is a nonparametric test procedure used for the analysis of matched-pair data or the one-sample problem. For a matched-pair setting, this procedure is used to evaluate the hypothesis that the probability distribution of the first sample is equal to the probability distribution of the second sample [22]. In this research, such a test will be used to compare the two different weather seasons (Dry-Wet) during the monitoring program (see Table 2).

\section{Principal component analysis}

The principal component analysis is a multivariate analysis technique that can be used to find new variables represented by a linear combination of variables having correlations via the variance-covariance matrix of several multivariate variables. The principal components (PC) are orthogonal variables obtained by multiplying the original correlated variables with the eigenvector. Principal components may be written as:

$\mathrm{z}_{\mathrm{ij}}=\mathrm{a}_{\mathrm{i} 1} \mathrm{x}_{1 \mathrm{j}}+\mathrm{a}_{\mathrm{i} 2} \mathrm{x}_{2 \mathrm{j}}+\ldots+\mathrm{a}_{\mathrm{im}} \mathrm{x}_{\mathrm{mj}}$

where $\mathrm{z}$ is the component score, $\mathrm{a}$ is the component loading, $\mathrm{x}$ is the variable value, $\mathrm{i}$ is the component number, $j$ is the sample number and $m$ is the total number of variables. Based on the loading coefficient and correlation

Table 1. Hypothesis testing for Colombian water law

\begin{tabular}{ll}
\hline Null Hypothesis & Alternative Hypothesis \\
\hline $\mathrm{H}_{0}: \mu_{\mathrm{DO}} \leq 4$ & $\mathrm{H}_{1}: \mu_{\mathrm{DO}}>4$ \\
$\mathrm{H}_{0}: \mu_{\mathrm{BOD}_{5}} \geq 3$ & $\mathrm{H}_{1}: \mu_{\mathrm{BOD}_{5}}<3$ \\
$\mathrm{H}_{0}: \mu_{\mathrm{COD}} \geq 1000$ & $\mathrm{H}_{1}: \mu_{\mathrm{COD}}<1000$ \\
$\mathrm{H}_{0}: \mu_{\mathrm{NH}_{4}^{+}} \geq 1$ & $\mathrm{H}_{1}: \mu_{\mathrm{NH}_{4}^{+}}<1$ \\
$\mathrm{H}_{0}: \mu_{\mathrm{TP}} \geq 0.003$ & $\mathrm{H}_{1}: \mu_{\mathrm{TP}}<0.003$ \\
$\mathrm{H}_{0}: \mu_{\mathrm{TSS}} \geq 90$ & $\mathrm{H}_{1}: \mu_{\mathrm{TSS}}<90$ \\
$\mathrm{H}_{0}: \mu_{\mathrm{pH}} \leq 6.5$ & $\mathrm{H}_{1}: \mu_{\mathrm{pH}}>6.5$ \\
$\mathrm{H}_{0}: \mu_{\mathrm{TC}} \geq 5000$ & $\mathrm{H}_{1}: \mu_{\mathrm{TC}}<5000$ \\
$\mathrm{H}_{0}: \mu_{\mathrm{FC}} \geq 1000$ & $\mathrm{H}_{1}: \mu_{\mathrm{FC}}<1000$ \\
$\mathrm{H}_{0}: \mu_{\mathrm{Sal}} \leq 33$ & $\mathrm{H}_{1}: \mu_{\mathrm{Sal}}>33$
\end{tabular}

Table 2. Hypothesis testing for dry-wet season comparison

\begin{tabular}{|c|c|}
\hline Null Hypothesis & Alternative Hypothesis \\
\hline $\mathrm{H}_{0}: \theta_{\text {Dry }}=\theta_{\text {Wet }}$ & $\mathrm{H}_{1}: \theta_{\text {Dry }} \neq \theta_{\text {wet }}$ \\
\hline
\end{tabular}


value with the PC. It explains most of the total variations with some important principal components. The new axes lie along the directions of maximum variance. PCA provides an objective way of finding indices of this type so that the variation in the data might be accounted for as concisely as possible [23-24].

\section{- RESULTS AND DISCUSSION}

\section{Statistical Resume}

A summary of the mean value and standard deviation of 10 measured variables in the lagoon water samples and the recommended value allowed by Colombian law for secondary contact is provided in Table 3.

Hypothesis tests showed that the oxygen values were above $5.70 \mathrm{mg} / \mathrm{L}$, which complies to the Colombian law with a confidence interval of 5.70-6.50 mg/L. OD may present high values, probably due to the presence of algae in the water, which during the photosynthesis process, consume carbon dioxide and produce oxygen. For BOD5 there was not enough information to conclude that the mean was lower than 3 , in fact, $90 \%$ of the time the value of this parameter was between [4.47-5.62 $\mathrm{mg} / \mathrm{L}$ ] which means that wastewater and solid wastes are deteriorating the quality of water in terms of organic material in the lagoon water [25]. The values for COD are high with values above the norm; this is possible due to the addition of chlorine from the sea because the lagoon is connected to it through different channels and also probably due to the chemicals coming from solid waste and anthropogenic activities like car wash services near the zone. Ammonium showed a confidence interval of $0.39-0.57 \mathrm{mg} / \mathrm{L}$ complying with environmental law. With a confidence of $90 \%$, the mean value for phosphorus was in the range $0.16-0.21 \mathrm{mg} / \mathrm{L}$. This parameter is out of the acceptable interval; this level indicates that water is near eutrophication which may be a threat for any species living in this habitat and may cause a bloom of different algae [26-27]. This is possible maybe due to the poor disposal of wastewater, water with soup or other kind of chemicals. Total suspended solid showed improvements because in the first years of the monitoring, the values were out of range, but lately, they became under control. In addition, $\mathrm{pH}$ showed good behavior with a confidence interval of 7.79-7.92, which complies with the law limits. Total and fecal coliforms are totally out of control in the Cabrero lagoon; this is evident due to the high number of outliers presented in the data above the threshold for this parameter. Total coliforms presented a confidence interval of 5509-29288 MPV, and fecal coliforms 1975.8-22648 MPV. These values represent a real threat for flora and fauna and the community around this lagoon, and the local government should take measures immediately in order to low these levels. Salinity varied from 26.1 to 27.5 possibly due to the entrance of freshwater from the communities around the lagoon. Results are depicted in Fig. 1.

\section{Temporal Variation in Water Quality}

Non-parametric Wilcoxon signed-rank test was performed in order to assess differences in the behavior

Table 3. Summary of descriptive statistics for water quality in Cabrero lagoon

\begin{tabular}{llllll}
\hline Parameter & Mean & SD & Min & Max & Guide level $^{*}$ \\
\hline DO & 6.11 & 1.82 & 1.02 & 9.04 & $>4$ \\
BOD5 & 5.10 & 5.62 & 1 & 13.58 & $<3$ \\
COD & 1014 & 379.5 & 261 & 2019 & $<1000$ \\
$\mathrm{NH}_{4}{ }^{+}$ & 0.49 & 0.42 & 0.07 & 1.65 & $<1$ \\
TP & 0.19 & 0.12 & 0.02 & 0.92 & $<0.003$ \\
TSS & 48.82 & 54.53 & 7 & 289 & $<90$ \\
pH & 7.85 & 0.304 & 7.17 & 8.64 & $6.5-8.5$ \\
TC (mpv) & 17398 & 54633 & 1.8 & $33 \cdot \times 10^{4}$ & $<5000$ \\
FC (mpv) & 12312 & 47496 & 1.8 & $33 \cdot \times 10^{4}$ & $<1000$ \\
Sal (\%o) & 27.79 & 7.81 & 9.2 & 37.3 & $33-36$ \\
\hline
\end{tabular}

${ }^{\star}$ Levels according to Colombian water law 

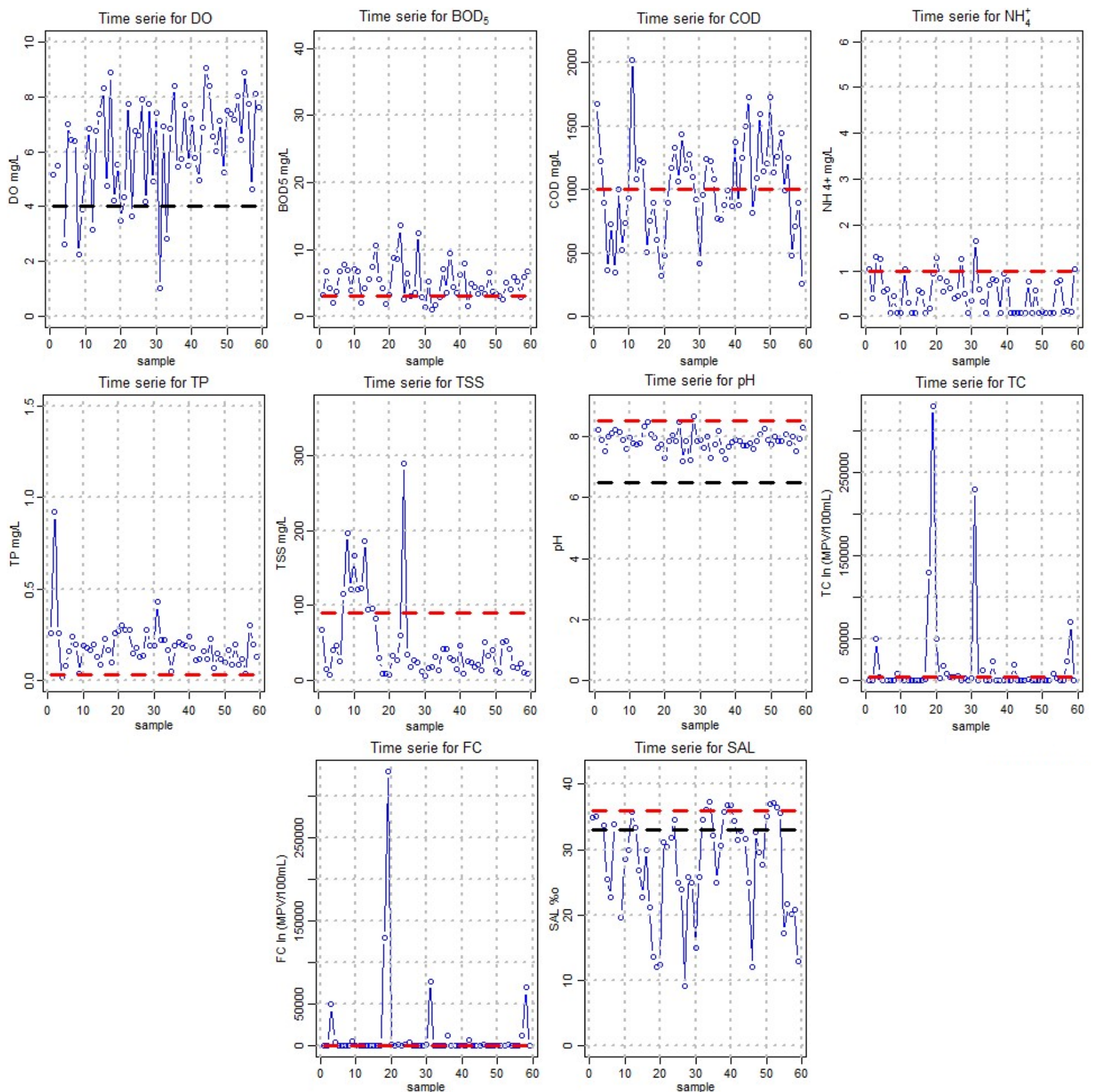

Fig 1. Time series for water quality parameters in Cabrera lagoon

of water quality in the dry and rainy season. As shown in Fig. 2, dissolved oxygen values were higher during the rainy season probably caused by the addition of freshwater. BOD5 presented a wider range during the dry season, possibly caused by the dilution of organic matter in the rainy season.
Values were above the threshold values during both seasons. COD presented no statistical difference between the dry and rainy season. Ammonium parameter was affected by the season $(\mathrm{p}<0.05)$. During dry season the values were higher and exceeding the limits according to Colombian laws. Total phosphorus 

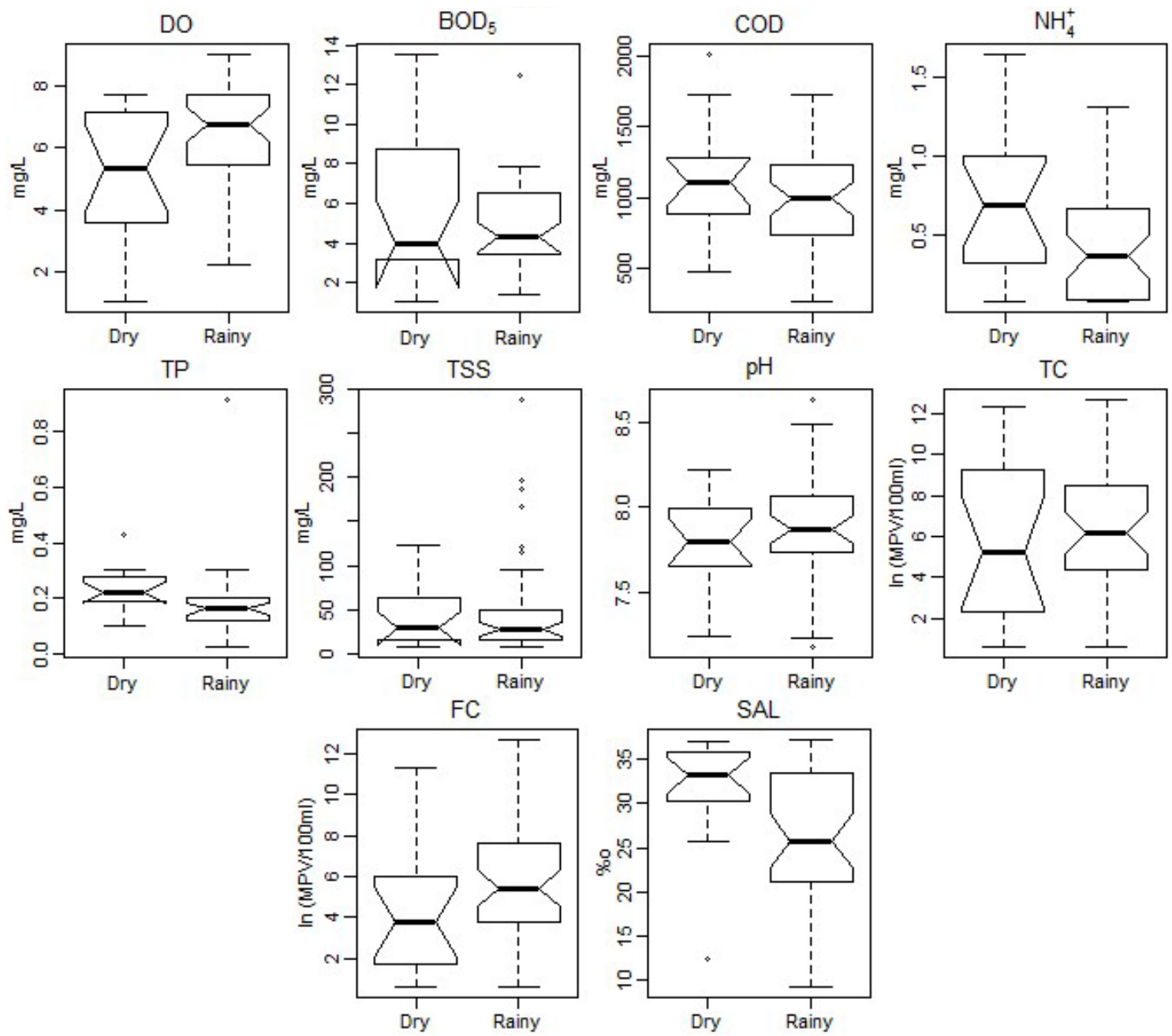

Fig 2. Temporal variation of water quality parameters

also presented statistical differences depending on the season $(p<0.05)$. In both seasons, values were outside of the allowed limits, especially during the dry season where the values were higher than in the rainy season.

Correlation between the seasons and suspended solids may also be explained in terms of the increased quantity of eroded material and urban run-off expected while raining; this is the reason for multiple outliers in the data. Comparing seasonal behavior for total coliforms, there is no significant difference between the seasons, but the values in both seasons are outside of the Colombian law limits. For fecal coliform, results showed that during the rainy season, values were higher, however there was no significant differences between the seasons. The nonsignificant correlation of total and fecal coliforms with seasons indicates the contribution of anthropogenic sources in the catchment areas. Salinity, as expected, presented a statistical difference between the dry and rainy season, which is caused by the entrance of freshwater during the rainy season. According to Fig. 2, levels of contaminants are out of limits no matter the season. The values reached by these parameters suggest the need for alternatives to reduce contaminants in aquatic ecosystems. It is also important to educate communities nearby the lagoon about the environmental impacts of throwing garbage and developing social projects around ecotourism activities.

\section{Principal Components Analysis}

The purpose of this analysis is to obtain a reduced number of linear combinations of the 10 variables that explain $79.4 \%$ of the total variance in the data set. In this 
Table 4. Loadings of experimental variables on significant components for all lagoon water samples

\begin{tabular}{lrrrrr}
\hline Parameters & PC1 & PC2 & PC3 & PC4 & \multicolumn{1}{c}{ PC5 } \\
\hline DO $(\mathrm{mg} / \mathrm{L})$ & 0.289 & $\mathbf{- 0 . 4 7 9}$ & 0.032 & $\mathbf{- 0 . 4 6 8}$ & 0.147 \\
BOD $_{5}(\mathrm{mg} / \mathrm{L})$ & 0.116 & 0.167 & $\mathbf{0 . 6 3 1}$ & -0.289 & -0.135 \\
COD $(\mathrm{mg} / \mathrm{L})$ & 0.296 & 0.340 & -0.302 & -0.251 & 0.421 \\
$\mathrm{NH}_{4}{ }^{+}(\mathrm{mg} / \mathrm{L})$ & -0.299 & 0.281 & 0.268 & 0.101 & -0.320 \\
$\mathrm{TP}(\mathrm{mg} / \mathrm{L})$ & -0.126 & $\mathbf{0 . 5 3 8}$ & 0.210 & -0.388 & 0.126 \\
$\mathrm{TSS}(\mathrm{mg} / \mathrm{L})$ & 0.194 & 0.096 & 0.250 & $\mathbf{0 . 6 7 6}$ & 0.332 \\
$\mathrm{pH}$ & 0.236 & -0.271 & $\mathbf{0 . 5 6 1}$ & 0.029 & 0.289 \\
$\mathrm{TC}(\mathrm{MPV})$ & $\mathbf{- 0 . 5 1 7}$ & -0.024 & 0.036 & -0.062 & 0.297 \\
$\mathrm{FC}(\mathrm{MPV})$ & $\mathbf{- 0 . 4 8 1}$ & -0.149 & 0.021 & -0.079 & 0.371 \\
Sal $(\mathrm{g} / \mathrm{kg})$ & 0.340 & 0.387 & -0.113 & 0.049 & 0.492 \\
\hline
\end{tabular}

case, 5 components were extracted since 5 components had eigenvalues greater than or equal to 1.0 .

An eigenvalue gives a measure of the significance of the factor; the factors with the highest eigenvalue are the most significant. The scree plot (see Fig. 3) was used to identify the number of Principal Components graphically.

The loading of five retained components is presented in Table 4. PC1 explains $28.56 \%$ of the variance and is highly contributed to the microbiological variables (total and fecal coliforms), this fecal factor represents the bacteriological pollution, essentially, originated from the domestic waste and poor disposal of human excrement. PC2 explains $15.15 \%$ of the variance and includes DO and TP. This factor mainly indicate the point sources of pollution by nutrients from domestic sewage. PC3 (13.89\% of variance) is positively contributed by $\mathrm{BOD}$ and $\mathrm{pH}$; it represents the variability of chemical and biological sources of discharge. PC4 (11.3\% of variance) is positively contributed by TSS, and negatively by DO; it represents pollution generated by eroded material and urban run-off. Finally, PC5, which explains $10.46 \%$ of the variance is positively contributed by COD and salinity and indicates the variability of different natural and anthropogenic ions entering the lagoon.

With these results (see Table 4) and in order to use Cabrero lagoon as an ecotourist attraction for its natural beauty, local authorities should carry out pollution prevention strategies focus on the reduction or elimination of waste from the source. This effort should involve the community living around the channel. Prevention is widely regarded as the most effective way to protect the environment.

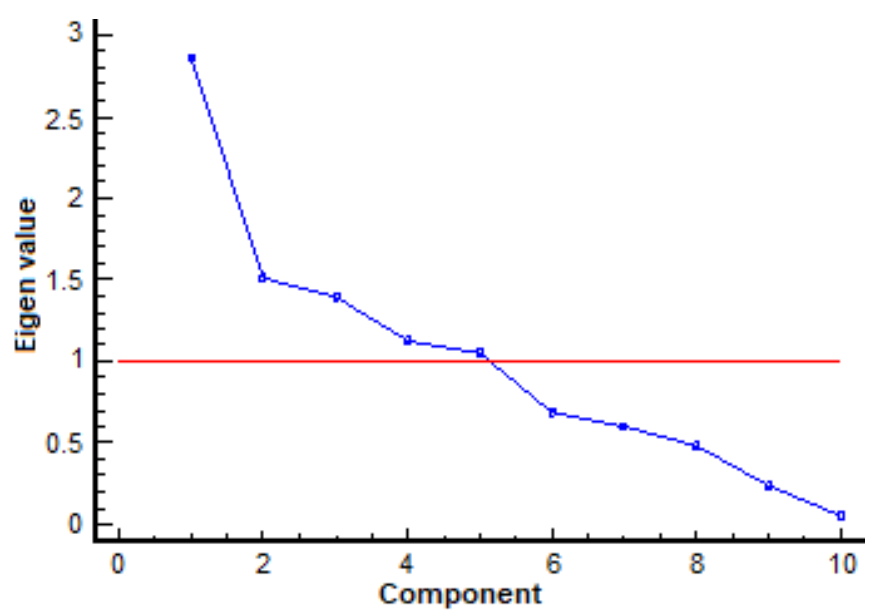

Fig 3. Scree plot for Principal Components Analysis in Cabrero lagoon

\section{- CONCLUSION}

In this study, surface water quality data for 10 parameters collected from 2008 to 2017 were analyzed using inferential statistics and multivariable statistical techniques. Most of the studied parameters presented many outliers which produced a non-normal distribution of data. Due to the high amount of data, hypothesis testing could be performed without any normalization technique. Microbiological and biochemical parameters were above the threshold values and reached dangerous levels. According to analysis results, Cabrero lagoon is presenting eutrophication problems in the dry and rainy season that may be caused by wastewater. The eutrophication leads to the high concentration of oxygen in the water due to the presence of algae that consume $\mathrm{CO}_{2}$, nitrogen and phosphorus during daylight in order to perform the 
photosynthesis process. The principal component analysis determined a reduced number of components that explained over $79 \%$ of the data set variance. Components obtained from PCA indicate that the parameters responsible for water quality variations are mainly related to anthropogenic and seasonal factors. Finally, this analysis showed the usefulness of inferential and multivariate statistical techniques serving as an exceptional exploratory tool in analysis and interpretation of complex data set on water quality, identification of pollution sources/factors and understanding temporal variations in water quality for effective management of the lagoon water quality.

\section{- ACKNOWLEDGMENTS}

The authors would like to thank Fundacion Universitaria Tecnologico Comfenalco, University of Cartagena and SENA for financially supporting this research.

\section{- REFERENCES}

[1] Newton, A., Brito, A.C., Icely' J.D., Derolez' V., Clara, I., Angus, S., Schernewski, G., Inácio, M., Lillebø, A.I., Sousa, A.I., Béjaoui, B., Solidoro, C., Tosic, M., Cañedo-Argüelles, M., Yamamuro, M., Reizopoulou, S., Tseng, H.C., Canu, D., Roselli, L., Maanan, M., Cristina, S., Ruiz-Fernández, A.C., de Lima, R.F., Kjerfve, B., Rubio-Cisneros, N., Pérez-Ruzafa, A., Marcos, C., Pastres, R., Pranovi, F., Snoussi, M., Turpie, J., Tuchkovenko, Y., Dyack, B., Brookes, J., Povilanskas, R., and Khokhlov, V., 2018, Assessing, quantifying and valuing the ecosystem services of coastal lagoons, J. Nat. Conserv., 44, 50-65.

[2] Alves, J.P.H., Fonseca, L.C., Chielle, R.S.A., and Macedo, L.C.B, 2018, Monitoring water quality of the Sergipe River basin: An evaluation using multivariate data analysis, Rev. Bras. Recur. Hídricos., 23, e27.

[3] Anteneh, Y., Zeleke, G., and Gebremariam, E., 2018, Assessment of surface water quality in Legedadie and Dire catchments, Central Ethiopia, using multivariate statistical analysis, Acta Ecol. Sin., 38 (2), 81-95.

[4] Pérez-Ruzafa, A., Marcos, C., and Pérez-Ruzafa, I.M., 2011, Mediterranean coastal lagoons in an ecosystem and aquatic resources management context, Phys. Chem. Earth, 36 (5-6), 160-166.
[5] Alvarez-Vázquez, A., and Olivella-Beltran, R., 2018, Hydraulic simulation of water bodies between the Cabrero's lagoon and the gates of Chambacú of the city of Cartagena - Colombia, Thesis, University of Cartagena, Colombia.

[6] Baldiris-Navarro, I., Sanchez-Aponte, J., GonzalezDelgado, A., Acosta-Jiménez, J.C., and Jiménez, A.R., 2018, Multivariable statistical evaluation of water quality in Juan Polo coastal lagoon (Colombian Caribbean), Contemp. Eng. Sci., 11 (27), 1339-1348.

[7] Azhar, S.C., Aris, A.Z., Yusoff, M.K., Ramli, M.F., and Juahir, H., 2015, Classification of river water quality using multivariate analysis, Procedia Environ. Sci., 30, 79-84.

[8] Alberto, W.D., del Pilar, D.M., Valeria, A.M., Fabiana, P.S., Cecilia, H.A., and de los Ángeles, B.M., 2001, Pattern recognition techniques for the evaluation of spatial and temporal variations in water quality. A case study: Suquía River Basin (CórdobaArgentina), Water Res., 35 (12), 2881-2894.

[9] Mitra, S., Ghosh, S., Satpathy, K.K., Bhattacharya, B.D., Sarkar, S.K., Mishra, P., and Raja, P., 2018, Water quality assessment of the ecologically stressed Hooghly River Estuary, India: A multivariate approach, Mar. Pollut. Bull., 126, 592-599.

[10] Taoufik, G., Khouni, I., and Ghrabi, A., 2017, Assessment of physico-chemical and microbiological surface water quality using multivariate statistical techniques: A case study of the Wadi El-Bey River, Tunisia, Arabian J. Geosci., 10, 181.

[11] Hajigholizadeh, M., and Melesse, A.M., 2017, Assortment and spatiotemporal analysis of surface water quality using cluster and discriminant analyses, Catena, 151, 247-258.

[12] Tosic, M., Restrepo, J.D., Lonin, S., Izquierdo, A., and Martins, F., 2019, Water and sediment quality in Cartagena Bay, Colombia: Seasonal variability and potential impacts of pollution, Estuarine Coastal Shelf Sci., 216, 187-203.

[13] Yoon, J.Y., Bhatta, K., Rastogi, G., Muduli, P.R., Do, Y., Kim, D.K., Pattnaik, A.K., and Joo, G.J., 2016, Application of multivariate analysis to determine spatial and temporal changes in water quality after 
new channel construction in the Chilika Lagoon, Ecol. Eng., 90, 314-319.

[14] Jung, K.Y., Lee, K.L., Im, T.H., Lee, I.J., Kim, S., Han, K.Y., and Ahn, J.M., 2016, Evaluation of water quality for the Nakdong River watershed using multivariate analysis, Environ. Technol. Innovation, 5, 67-82.

[15] Jiang, Y., Guo, H., Jia, Y., Cao, Y., and Hu, C., 2015, Principal component analysis and hierarchical cluster analyses of arsenic groundwater geochemistry in the Hetao basin, Inner Mongolia, Geochemistry, 75 (2), 197-205.

[16] Ruždjak, A.M., and Ruždjak, D., 2015, Evaluation of river water quality variations using multivariate statistical techniques: Sava River (Croatia): A case study, Environ. Monit. Assess., 187, 215.

[17] DIMAR, 2017, Weather conditions in Cartagena de Indias, Centro de Investigaciones Oceanograficas e Hidrograficas, https://www.cioh.org.co/meteorologia/ Climatologia/Climatologia\%20Cartagena.pdf, accessed on 10 January 2019.

[18] Baird, R., Eaton, A.D., and Rice, E.W., 2017, Standard Methods for the Examination of Water and Wastewater, $23^{\text {rd }}$ Ed., American Public Health Association, American Water Works Association, Water Environment Federation.

[19] Acosta, J.C., Baldiris, I., and Pacheco, H.P., 2015, Análisis de la variación en la calidad del agua en la bahía de Barbacoas-Cartagena durante el period 2001-2014, Rev. Ingeniería Innovación, 3 (1), 7-17.

[20] Montgomery, D.C., Runger, G.C., and Hubele, N.F., 2010, Engineering Statistics, $5^{\text {th }}$ Ed., John Wiley \& Sons, New York.

[21] Navarro, I.B., and Aponte, J.H.S., 2017, Application of multivariate statistical methods to water quality assessment in Arroyo Plata, Colombian Caribbean, Teknos Revista Científica, 17, 11-21.

[22] Woolson, R.F., 2008, "Wilcoxon signed-rank test" in Wiley Encyclopedia of Clinical Trials, Eds. D’Agostino, R.B., Sullivan, L., and Massaro, J., John Wiley \& Sons, 1-3.

[23] Razmkhah, H., Abrishamchi, A., and Torkian, A., 2010, Evaluation of spatial and temporal variation in water quality by pattern recognition techniques: A case study on Jajrood River (Tehran, Iran), J. Environ. Manage., 91 (4), 852-860.

[24] Kaveh, A.R., Shahedi, K., Roshan, M.H., and Ghorbani, J., 2015, Assessment of spatio-temporal variations of surface water quality and prioritization of pollution Sources (Case study: Talar Watershed, Mazandaran province), Environ. Resour. Res., 3, 27-45.

[25] Barakat, A., El Baghdadi, M., Rais, J., Aghezzaf, B., and Slassi, M., 2016, Assessment of spatial and seasonal water quality variation of Oum Er Rbia River (Morocco) using multivariate statistical techniques, Int. Soil Water Conserv. Res., 4 (4), 284-292.

[26] Ménesguen, A., and Lacroix, G., 2018, Modelling the marine eutrophication: A review, Sci. Total Environ., 636, 339-354.

[27] Cutrim, M.V.J., Ferreira, F.S., dos Santos, A.K.D., Cavalcanti, L.F., Araújo B.O., de Azevedo-Cutrim, A.C.G., Furtado, J.A., and Oliveira, A.L.L., 2019, Trophic state of an urban coastal lagoon (northern Brazil), seasonal variation of the phytoplankton community and environmental variables, Estuarine Coastal Shelf Sci., 216, 98-109. 